\title{
Metode Index Card untuk Meningkatkan Hasil Belajar Mapel IPS Kelas VI SD
}

\author{
Suwarni AI Suawrtiani ${ }^{(1)}$ \\ ${ }^{1}$ SD Negeri 1 Sumberbening Dongko Trenggalek,

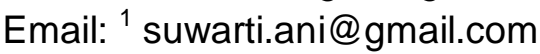

\begin{abstract}
ABSTRAK
Mata pelajaran IImu Pengetahuan Sosial (IPS) seringkali dianggap sulit sehingga banyak siswa yang kurang memahami dan mencapai nilai relatif rendah. Kesulitan disebabkan materi yang cukup luas, selalu berkembang, metode ceramah yang digunakan pendidik dan cara belajar siswa yang kurang tepat. Pendidikan IPS berfungsi mengembangkan kemampuan dan membentuk watak serta peradaban bangsa yang bermartabat dalam rangka mencerdaskan kehidupan bangsa, bertujuan untuk berkembangnya potensi peserta didik agar menjadi manusia yang beriman dan bertaqwa kepada Tuhan Yang Maha Esa, berakhlaq mulia, sehat, berilmu, cakap, kreatif, mandiri, dan menjadi warga negara yang demokratis serta bertanggung jawab. Tujuan penelitian ini adalah mengetahui gambaran objektif tentang penigkatan hasil belajar maple IPS materi gejala alam pada siswa kelas VI SD Negeri 1 Sumberbening Kecamatan Dongko degan metode index card match semester II tahun pelajaran 2016/2017. Penelitian menunjukkan bahwa penerapan metode index card match dapat meningkatkan hasil belajar IPS materi gejala alam yang terjadi di Indonesia dan sekitarnya. Nilai yang tidak memenuhi KKM pada' pra-siklus $(77,78 \%)$, setelah menggunakan penerapan metode index card match pada siklus 1 menjadi $(55,56 \%)$, dan siklus II menjadi $(13,89 \%)$ dan ketuntasan belajar IPS dapat dilihat dari rata-rata hasil tes pada setiap siklus yaitu pra-siklus $(22,22 \%)$, siklus I menjadi $(46,7 \%)$, siklus II menjadi $(80,77 \%$.). Jadi, dari pra siklus ke siklus II nilai rata-rata hasil belajar meningkat sebesar 21,67 .
\end{abstract}

Kata kunci: Index Card Match, Hasil Belajar IPS,

\section{PENDAHULUAN}

Pendidikan merupakan tanggung jawab bersama antara keluarga, sekolah, masyarakat, dan pemerintah. Pendidikan dapat berlangsung di dalam lingkungan keluarga dan masyarakat. Pendidikan adalah usaha yang dianggap penting guna menjaga keselamatan bangsa dan negara. Ki Hajar Dewantara memngemukakan bahwa pendidikan adalah tuntutan di dalam tubuh anak-anak. Adapun maksudnya pendidikan yaitu menuntun segala kekuatan kodrat yang ada pada anak-anak itu, agar mereka sebagai manusia dan sebagai anggota masyarakat dapatlah mencapai keselamatan dan kebahagiaan setinggi-tingginya (Haryanto, 2012:55). Untuk mencapai semua itu diperlukan adanya kerjasama yang baik antara keluarga, sekolah, masyarakat, dan pemerintah. Bahkan karena sangat pentingnya dalam hal masalah pendidikan, pemerintah sangat mengapresiasi sehingga lahirlah UU NO 14 Tahun 2005 tentang guru dan dosen bahwa guru adalah pendidik professional dengan tugas utama mendidik, mengajar, membina, membimbing, mengarahkan, melatih, menilai, dan mengevaluasi peserta didik. Ditegaskan pula bahwa guru berfungsi untuk meningkatkan martabat dan peran guru sebagai agen pembelajaran untuk meningkatkan mutu pendidikan nasional (Suwandi, 2008:11).

Pembelajaran IPS umumnya membutuhkan kemampuan siswa untuk menghafal materi, sehingga dibutuhkan metode pembelajaran yang membuat siswa menghafal tanpa ada rasa bosan. Salah satunya adalah metode index card match. Peningkatan kualitas pendidikan disekolah dapat di tempuh dengan berbagai cara, antara lain: peningkatan kurikulum, peningkatan kompetensi guru, peningkatan kualitas pembelajaran, efektivitas metode pembelajaran, peningkatan sarana dan prasarana belajar dan bahan ajar yang memadai. Menurut Sardiman (2004:67) tugas dan 
peranan guru antara lain menguasai dan mengembangkan materi pelajaran, merencanakan dan mepersiapkan pelajaran sehari-hari, mengontrol dan mengevaluasi kegiatan siswa.

Keberhasilan pendidikan tidak terlepas dari peran guru yang merupakan komponen pendidikan yang terlibat langsung dalam pelaksanaan Kurikulum Satuan Pendidikan (KTSP) di lapangan. Guru sebagai ujung tombak dalam pelaksanaan pendidikan merupakan pihak yang sangat berpengaruh dalam proses pembelajaran. Kepiawaian dan kewibawaan guru sangat menentukan kelangsungan proses pembelajaran dikelas maupun efeknya diluar kelas. Guru harus pandai membawa siswanya kepada tujuan yang hendak dicapai. Guru memiliki peranan yang sangat penting sehubungan dengan tugasnya sebagai perencana dan pelaksana sekaligus mengevaluasi kegiatan Belajar mengajar (KBM). Guru sebagai pelaksana utama pendidikan dan pelajaran sekolah, maka guru dituntut untuk mampu menerapkan Kurikulum Satuan Pendidikan (KTSP) dalam kegiatan pembelajaran. Guru dan siswa diharapkan dapat mengetahui apa yang harus dicapai dan sejauh mana efektivitas belajar dicapai. Kurikulum Satuan Pendidikan (KTSP) merupakan suatu format untuk menetapkan suatu kompetensi yang diharapkan siswa dalam setiap tingkat dan mengambarkan langkah kemajuan siswa menuju kompetensi yang lebih tinggi. Peran guru sebagai pemberi ilmu sudah saatnya berubah menjadi fasilitator yang memfasilitasi siswa untuk dapat belajar dan mengkontruksi pengetahun mereka sendiri. Proses belajar tidak harus dari guru, siswa bisa saling mengajar dengan siswa yang lainnya.

Menurut Silberman (2010:246), Index Card Match merupakan cara yang menyenangkan dan aktif untuk mengkaji materi pembelajaran. Dengan metode index card match siswa dapat aktif dalam proses pembelajaran, siswa akan belajar menyampaikan sesuatu pemahaman pada teman serta dapat menjadi pendengar yang baik saat teman lain menyampaikan suatu pemahaman, sehingga siswa memiliki antusias dalam proses pembelajaran untuk berlomba-lomba mencari pasangan dari setiap kartu yang dia miliki baik kartu yang berisi pertanyaan maupun kartu yang berisi jawaban.

Belajar merupakan suatu usaha sadar individu untuk mencapai tujuan peningkatan diri atau perubahan diri melalui latihan-latihan dan pengulanganpengulangan dan perubahan yang terjadi bukan karena kebetulan (Mulyati, 2005:5). Slameto (1995:2) mengemukakan bahwa belajar adalah suatu proses usaha yang dilakukan seseorang untuk memperoleh suatu perubahan tingkah laku yang baru secara keseluruhan, sebagai hasil pengalamannya sendiri dalam interaksi dengan lingkungannya. Menurut Guilford dalam Mustaqim (2004:34) belajar adalah perubahan tingkah laku yang dihasilkan dari rangsangan.

Berdasarkan berbagai pengertian belajar menurut beberapa ahli di atas dapat dikatakan bahwa pengertian belajar adalah terjadinya perubahan pada orang yang belajar, perubahan tampak dari belum mampu menjadi mampu. Perubahan-perubahan dapat berupa sesuatu yang baru, yang segera nampak dalam perilaku nyata atau yang masih tersembunyi, mungkin juga perubahan hanya berupa penyempurnaan terhadap hal yang sudah dipelajari. Kaitannya dengan hasil belajar, Susanto (2013:5) membagi ke dalam tiga kawasan yaitu kognitif, afektif dan psikomotorik. Hasil belajar kaitan erat dengan proses belajar sehingga faktor yang mempengaruhi belajar akan berpengaruh terhadap hasil belajar. Seperti apa yang diutarakan Sriyanti (2009:23) terdapat dua faktor yang mempengaruhi keberhasilan belajar yaitu faktor internal dan faktor eksternal.

Metode pembelajaran adalah cara yang dipergunakan guru dalam mengadakan hubungan dengan siswa pada saat berlangsung pembelajaran (Sudjana, 2005:76). Metode pembelajaran cara yang digunakan untuk mengimplementasikan rencana yang sudah disusun dalam kegiatan nyata agar tujuan yang telah disusun tercapai secara optimal (Wina Sanjaya, 2008:147). Menurut Abdurrahman Ginting, (2008:42) metode pembelajaran dapat diartikan cara atau pola yang khas dalam 
memanfaatkan berbagai prinsip dasar pendidikan serta berbagai teknik dan sumberdaya terkait lainnya agar terjadi proses pembelajaran pada diri pembelajar.

Cepat lambatnya peserta didik dalam belajar IPS sangat erat kaitannya dengan metode yang dipakai karena berpengaruh dengan cocok apa tidaknya metode itu diterapkan. Index Card Match adalah cara menyenangkan lagi aktif untuk meninjau ulang materi pembelajaran. la membolehkan peserta didik untuk berpasangan dan memainkan quiz kepada lawan sekelas Index Card Match merupakan cara yang menyenangkan dan aktif untuk mengkaji materi pembelajaran. Para peserta bermain dalam sebuah kuis dan berpasangan (Mel. Silberman, 2010: 236-246). Index Card Match adalah salah satu teknik instruksional dari belajar aktif yang termasuk dalam berbagai reviewing strategis (strategi pengulangan) (Mel. Silberman, 2006:250). Metode Index Card Match ini berhubungan dengan cara-cara untuk mengingat kembali apa yang telah mereka pelajari dan menguji pengetahuan serta kemampuan mereka saat ini dengan teknik mencari pasangan kartu yang merupakan jawaban atau soal sambil belajar mengenai suatu konsep atau topik dalam suasana menyenangkan. Biasanya guru dalam kegiatan belajar mengajar memberikan banyak informasi kepada siswa agar materi ataupun topik dalam program pembelajaran dapat terselesaikan tepat waktu, namun guru terkadang lupa bahwa tujuan pembelajaranbukan hanya materi yang selesai tepat waktu tetapi sejauh mana materi telah disampaikan dapat diingat oleh siswa. Karena itu dalam kegiatan pembelajaran perlu diadakan peninjauan ulang atau review untuk mengetahui apakah materi yang disampaikan dapat dipahami oleh siswa.

Fungsi Index Card Match agar anak-anak lebih cepat dalam pembelajaran, anak akan lebih mudah dalam memahami suatu materi, dan tidak merasa kejenuhan dalam pembelajaran. Langkah-langkahnya tulislah dalam kartu indeks terpisah nama teknik/atau konsep yang telah dipelajari pada sesi pelatihan (misalnya,"diskusi fish bowl") dan buat kartu-kartu tersebut sebanyak setengah jumlah peserta, pada kartu lain yang terpisah, tulislah definisi yang tepat atau cntoh-contoh yang jelas tentang teknik dan konsep tersebut. Misalnya, diskusi fish bowl adalah "cara untuk mengadakan diskusi kelompok kecil dalam lingkup kelompok besar", gabungkan dua kelompok kartu tersebut dan kocoklah beberapa kali sehingga teracak sempurna, bagikan satu kartu pada setiap peserta. Jelaskan pada mereka bahwa ini adalah permainan mencocokkan kartu. Sebagian peserta memegang kartu yang bertuliskan nama teknik atau konsep yang dipelajari dalam sesi pelatihan, dan sebagian peserta lainnya memegang kartu bertuliskan definisi atau contoh-contohnya, seluruh para peserta menemukan pasangan kartunya. Apabila sudah terbentuk pasanganpasangan, mintalah setiap pasangan untuk duduk bersebelahan. (beri tahu mereka untuk tidak membuka kartu masing-masing, dan selanjutnya apabila semua pasangan (dengan kartu-kartunya yang telah berpasangan) sudah duduk, salah satu anggota pasangan menanyakan pada semua peserta lain tentang teknik atau konsep yang ada di kartu mereka, dengan cara membacakan definisi atau contoh-contohnya.

\section{METODE}

Penelitian yang dilakukan mengunakan penelitian tindakan kelas, istilah dalam bahasa Inggrisnya adalah Classroom Action Research (CAR) atau PTK, dikemas dan dilakukan untuk memperbaiki mutu praktik dalam pembelajaran dikelasnya (Arikunto, 2007:58). Karakteristik yang khas dari penelitian tindakan kelas adanya aksi tertentu untuk memperbaiki proses belajar mengajar dikelasnya, (Arikunto, 2007:107). Subjek penelitian adalah siswa kelas VI SDN 1 Sumberbening, dengan jumlah siswa 26 orang dengan siswa laki-laki 12 orang dan siswi perempuan 14 orang. Instrumen penelitian yang digunakan dalam penelitian ini adalah lembar pengamatan/observasi metode index cardmatch dan tes. Tes/soal merupakan seperangkat rangsangan (stimulus) yang diberikan kepada seseorang dengan maksud untuk mendapatkan jawabanjawaban yang dijadikan skor angka (Hamdani, dkk, 2008:77), digunakan untuk mengetahui berhasil tidaknya siswa dalam menguasai materi setelah menggunakan 
penerapan metode index cardmatch. Peneliti akan menggunakan tes objektif yaitu pilihan ganda (multiple choice test), dan uraian.

Data sebagaimana adanya dianalisa, diolah, dan disusun sedemikian rupa sehingga bisa digunakan untuk membuktikan kebenaran hipotesis yang telah dirumuskan. Dalam membuktikan hipotesis maka hasil penelitian dilakukan analisis dengan menghitung nilai rata-rata kelas dengan rumus sebagai berikut: $M=\frac{\sum x}{N} \quad$ Keterangan, $\mathrm{M}=$ Nilairata-rata, $\sum x=$ Jumlah semua nilai siswa, $\mathrm{N}=$ Jumlahsiswa (Djamarah,2006:64), selanjutnya menghitung presentase ketuntasan belajar siswa, digunakan rumus sebagaiberikut:

$$
\mathrm{P}=\frac{F}{N} \mathrm{x} 100 \% \quad \begin{aligned}
& \text { Keterangan: } \mathrm{P}=\text { nilai dalam persen } \mathrm{F}=\text { Frekuensi, } \mathrm{N}= \\
& \text { Jumlah keseluruhan (Djamarah, 2006:225-226) }
\end{aligned}
$$

\section{HASIL \\ Pra Siklus}

Guru menggunakan metode ceramah dan penugasan. Guru sebagai penyampai materi sedangkan siswa hanya sebagai pendengar yang selesai mendengar kemudian mengerjakan latihan, hasil penelitian pra siklus yang diambil dari 26 siswa di kelas VI hanya 11 siswa yang berhasil memenuhi standar Kriteria Ketuntasan Minimal (KKM). Untuk Kriteria ketuntasan minimal pada mata pelajaran IPS adalah 65, artinya masih ada 15 siswa yang masih mengalami kesulitan dalam pembelajaran dan belum mencapai $50 \%$ dari jumlah siswa, sehingga perlu untuk memperbaiki keadaan tersebut. Refleksi dari data ditarik kesimpulan bahwa pada prasiklus terdapat permasalahan adanya beberapa siswa yang kurang memperhatikan, karena penyajian materi denganceramah, adanya beberapa siswa yang belum mendapatkan nilai sesuai dengan standar ketuntasan, hal ini dikarenakan karena masih menggunakan strategi pembelajaran yangmonoton, guru kurang berinteraksi dengan siswa, sehingga masih ada siswa yang bicara sendiri, dan guru kurang melibatkan siswa ketika proses pembelajaran sehingga siswa tidak berani untuk aktif atau bertanyajawab. Secara garis besar pra-siklus berjalan baik dan kondusif, walaupun hasil belajar siswa belum mencapai standar nilai KKM yang ditentukan yaitu 65 untuk mata pelajaran IPS di SDN 1 Sumberbening Kecamatan Dongko. Hal ini harus dijadikan suatu yang harus dibenahi dalam pelaksanaan siklus I.

\section{Siklus I}

Pelaksanaan tindakan kelas pada siklus I dilaksanakan pada semester II selama kurang lebih 2 jam pelajaran $(2 \times 35)$ dengan 4 (empat) tahap yaitu, dengan alur perencanaan (planning), tindakan (acting). Pengamatan (observing), dan refleksi (reflecting). Tahap perencanaan guru menentukan sub pokok bahasan yang akan diajarkan yaitu, memahami gejala alam yang terjadi di Indonesia dansekitarnya, merancang rencana pembelajaran sebagai dalam kegiatan belajar mengajar, merancang kegiatan pembelajaran dengan alat dan bahan yang diperlukan, merancang soal-soal sarana untuk mengetahui kemampuansiswa, merancang atau menyiapkan lembar observasi/pengamatan untuk guru, guna mengetahui perubahan danpengembangan, merancang atau menyiapkan lembar observasi untuk siswa, guna untuk mengetahui perubahan danpengembangan, dan mengunakan media pembelajaran sesuai dengankebutuhan. Tahap tindakan dilaksanakan sesuai rancangan pembelajaran, tahap pengamatan dilaksanaakan observasi/pengamatan terhadap pelaksanaan pembelajaran berlangsung, siswa tuntas $12(46,7 \%)$, tidak tuntas $14(53,86 \%)$.

\section{Siklus II}


Pelaksanaan tindakan kelas pada siklus II dilakukan dalam 4 (empat) tahap, yaitu, dengan alur perencanaan (planning), tindakan (acting), pengamatan (observing), dan refleksi (reflecting) dengan memperhatikan dan mempertimbangkan kajian pada siklus 1. Tahap perencanaan, perbaikan pembelajaran dengan berupaya meningkatkan partisipasi keaktifan dan pemahaman siswa, serta hasil dalampembelajaran. Tahap tindakan dilakukan pembelajaran sesuai dengan pembelajaran dengan model Index Card Match, hasil pengamatan pada siklus ini terjadi perbaikan yang signifikan dari proses pembelajaran pada siklus 1 yakni siswa sudah menunjukan partisipasi dalam pembelajaran, menunjukan peningkatan dan pemahaman, siswa menunjukkan perubahan yang lebih baik di banding dengan siklus I. Hasil pengamatan pada siklus 2 siswa dalam kajian 26 dalam satu kelas terdapat siswa tuntas sebanyak 21 siswa $(80,77 \%)$ dengan siswa yang belum tuntas sebanyak 5 siswa $(19,23 \%)$, dengan indeks nilai tertinggi 100 dan nilai terendah 40 dengan ratarata kelas 70,77 .

\section{PEMBAHASAN}

Setelah dilakukan perencanaan, tindakan dan pengamatan, peneliti bersama kolaborator mengadakan refleksi dan tindakan-tindakan yang telah dilakukan dengan menganalisis tingkat perubahan kemampuan siswa sebelum dan sesudah dilakukan tindakan, maka perlu dilakukan kembali perbaikan pada pelaksanaan pembelajaran pada siklus 2 dengan memperbaiki beberapa kendala yang menyebabkan hasil siklus 1 tidak dapat maksimal.

Berdasarkan hasil skor tes pada siklus II dapat dikatakan bahwa penerapan metode pembelajaran index card match terbukti dapat meningkatkan pemahaman siswa pada materi IPS materi gejala alam pada siswa kelas VI SDN 1 Sumberbening Kecamatan Dongko Kabupaten Treggalek pada semester II tahun pelajaran 2016/2017. Hal ini dapat dibuktikan dengan adanya peningkatan pemahaman siswa dalam belajar dan hasil belajar IPS yang diperoleh.

\section{KESIMPULAN}

Berdasarkan hasil penelitian dan pembahasannya dapat disimpulkan bahwa penerapan metode pembelajaran index card match terbukti dapat meningkatkan hasil belajar IPS materi gejala alam pada siswa kelas VI SDN 2 Sumberbening Kecamatan Dongko Kabupaten Trenggalek pada semester II tahun pelajaran 2016/2017. Untuk angka ketuntasan belajar siswa dari pra siklus ke siklus I naik menjadi 12 anak atau sebesar $46,15 \%$ dan menjadi 20 anak pada siklus II atau sebesar $80 \%$. Dan angka ketuntasan belajar pada siklus II sebanyak 21 anak atau sebesar $80,77 \%$.

\section{SARAN}

Berdasarkan hasil penelitian ini, peneliti dapat disampaikan saran sebaiknya dalam kegiatan belajar mengajar diharapkan guru menjadikan metode index card match sebagai suatu alternatif dalam pembelajaran IPS, sehingga situasi pembelajaran dapat menyenangkan, iovatif, dan kreatif. Siswa hendak meningkatkan kesadaran untuk selalu berpartisipasi aktif dalam setiap kegiatan belajar mengajar, siswa juga hendaknya tidak takut atau malu untuk menanyakan tentang materi peajaran yang belum dipahami. Dan sekolah dengan supervisinya hendaknya selalu mendorong para guru yang berusaha menggunakan strategi pembelajaran yang bersifat inovatif dan kreatif dengan memfasilitasi sarana dan prasarana yang dibutuhkan selain itu juga melatih para guru agar kompetensinya meningkat. Kepada peneliti selanjutnya yang akan melakukan penelitian dalam bidang yang sama, agar dapat menindak lanjuti penelitian ini dalam kancah yang lebih luas, sehingga diperoleh hasil yang lebih baik yang nantinya akan dapat berguna meningkatkan kualitas pendidikan dilndonesia. 


\section{DAFTAR RUJUKAN}

Ahmadi, Abu. 1997. Ilmu Sosial Dasar. Jakarta: PT. Rineka Cipta.

Ahmadi, Abu. 2005. Strategi Belajar Mengajar. Bandung: CV Pustaka Setia.

Arikunto, Suharsimi. 1995. Dasar-dasar Evaluasi Pendidikan. Jakarta: Bumi Aksara.

Arikunto, Suharsimi. 2007. Penelitian Tindakan Kelas. Jakarta: Bumi Aksara.

Arikunto, Suharsimi. 2008. Penelitian Tindakan Kelas. Jakarta: Bumi Aksara.

Basrowi, Suwandi. 2008. Prosedur Penelitian Tindakan Kelas. Jakarta: Galia Indonesia.

Departemen Agama. 2004. Standar Kompetensi Madrasah Ibtidaiyah. Jakarta: Direktorat Jendral Kelembagaan Agama Islam.

Djamarah, Aswan. 2006. Strategi Belajar Mengajar. Jakarta: Rineka Cipta.

Ginting, Abdurrahaman. 2008. Esensi Praktis Belajar dan Pembelajaran. Bandung: Humaniora.

Haryanto. 2012. Pengertian Pendidikan Menurut Ahli,(Online) http://belajarpsikologi.com/pengertiaokologi.com/pengertian-pendidikanmenurut-ahli/, diakses pada tanggal 5 November 2014.

Mel. Silberman. 2001. Aktive Learning 101 Strategi Pembelajaran Aktif. Yogyakarta: Yappendis.

Mel. Silberman. 2006. Aktive Learning 101 Strategi Pembelajaran Aktif. Yogyakarta: Yappendis.

Mel. Silberman. 2010. 101 Cara Pelatihan dan Pembelajaran Aktif. Jakarta: PT Indexs.

Mulyati. 2005. Psikologi Belajar. Yogyakarta: Andi Offset.

Mustaqim. 2004. Psikologi Pendidikan. Semarang: FakultasTarbiyah IAIN Walisongo Semarang.

Purwanto, Ngalim. 1988. Psikologi Pendidikan. Bandung: RemajaKarya.

Rasimin. 2012. Pendidikan IImu Pengetahuan Sosial Teoridan Aplikasi. Yogyakarta: Trust Media Publising.

Sam's, Rosma Hartiny. 2010. Model Penelitian Tindakan Kelas. Yogyakarta: Sukses Offset.

Sanjaya, Wina. 2008.Strategi Pembelajaran Berorientasi Standar Proses Pendidikan. Jakarta: Kencana Prenada Media Group.

Sardiman A.M, 1989. Interaksi dan Motivasi Belajar Mengajar, Jakarta: Rajawali Press.

Slameto. 1995. Belajar dan Faktor-Faktor yang Mempengaruhinya. Jakarta: RinekaCipta.

Sriyanti, Lilik, dkk. 2009. Teori-teori Belajar. Salatiga: STAIN Salatiga Press.

Sudjana, Nana. 1989. Cara Belajar Siswa Aktif-Dalam Proses Belajar Mengajar. Bandung: Sinar Baru.

Suprijono, Agus. 2007. Cooperatif Learning, Teori dan Aplikasi Paikem. Jakarta: PustakaPelajar. 